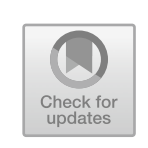

\title{
Hearing the Form: Breath and the Structures of Poetry in Charles Olson and Paul Celan
}

\section{David Fuller}

A group of mid-twentieth-century American poets, of whom Charles Olson is the most prominent theorist and William Carlos Williams the best-known poet, experimented with new forms for poetry with a declared aim of structuring poems in new ways. Olson particularly experimented with structuring by rhythms related not to the pulse (which is one way of understanding the relatively regular beat of European poetry) but to the breath - a different kind of measure, still bodily, but more fluid. One aim of Olson and his associates was a new freedom with form by which they could be both distinctively modern and distinctively American. For readers acculturated to the rhythms of European poetry there can be problems about hearing these forms, especially insofar as they are involved with American patterns of speech. ${ }^{1}$

To hear this poetry a reader needs to consider how these poets theorised about writing, listen to what they did in actual reading, and compare their theories of composition and practices of performance with poems

D. Fuller $(\bowtie)$

University of Durham, Durham, UK

(C) The Author(s) 2021

409

D. Fuller et al. (eds.), The Life of Breath in Literature, Culture

and Medicine, Palgrave Studies in Literature, Science and Medicine, https://doi.org/10.1007/978-3-030-74443-4_20 
as they appear on the page. While some areas of what was new in midtwentieth-century American poetry were taken up in Britain-Marianne Moore, Robert Lowell, John Berryman, Elizabeth Bishop-the Olson group remained on the fringes. Outside a coterie of poets (most prominently J. H. Prynne and his associates), English ears have mostly not learned to hear it. ${ }^{2}$

Breath is central to the issue of these new structures. The foundational manifesto is Olson's Projective Verse (1950).

Verse now, 1950, if it is to go ahead, if it is to be of essential use, must, I take it, catch up and put into itself certain laws and possibilities of the breath, of the breathing of the man who writes as well as of his listenings. ...

If I hammer, if I recall in, and keep calling in, the breath, the breathing as distinguished from the hearing, it is for cause, it is to insist upon a part that breath plays in verse which has not (due, I think, to the smothering of the power of the line by too set a concept of foot) has not been sufficiently observed or practiced, but which has to be if verse is to advance to its proper force and place in the day, now, and ahead. I take it that PROJECTIVE VERSE teaches, is, this lesson, that that verse will only do in which a poet manages to register both the acquisitions of his ear and the pressure of his breath. ...

Together ... the syllable and the line, they make a poem, they make that thing, the-what shall we call it, the Boss of all, the 'Single Intelligence'. And the line comes (I swear it) from the breath, from the breathing of the man who writes, at the moment that he writes, and thus is, it is here that, the daily work, the WORK, gets in, for only he, the man who writes, can declare, at every moment, the line its metric and its ending-where its breathing, shall come to, termination. ...

Let me put it baldly. The two halves are:

the HEAD, by way of the EAR, to the SYLLABLE the HEART, by way of the BREATH, to the LINE. ...

I say a projective poet will [go], down through the workings of his own throat to that place where breath comes from, where breath has its beginnings, where drama has to come from, where, the coincidence is, all act springs. ${ }^{3}$

Olson rejects ideas of verse rhythm recognised by millennia of European poetry - the idea of patterns of grouped stresses in the poetic line, variable, but with an underlying regularity. He replaces this with a fundamentally different and more variable structure, not grouped by stresses, 
but understood by the idea of each line as an out-breathing. There is no reference to pre-existing conventions of poetic structure: 'only he ... who writes, can declare, at every moment, the line its metric and its ending'. Just two structural elements, the syllable and the line, make the poem's form a comprehensive address to the head and the heart, the intelligence and the feelings. This idea of forms that engage the whole person stresses the entire physiology of breathing - through the throat, down to where breathing begins, in the diaphragm, and the network of muscles and tendons that support the whole breathing apparatus.

Olson does not only describe ideas about expression: he enacts them. His prose style rejects the norms of written discourse in favour of imitating speech-repetitions for emphasis, piled up clauses, colloquial diction, extended turning aside into parenthetical clauses, slides and slithers from one syntactic construction into another. Flagrantly violating norms of 'correct' written style, Olson enjoins the use of, and he uses, phrasings by the breath. In his prose as in his poetry, the reader who realises the page as implied aural structures hears Olson breathe.

Two issues that Olson refers to but does not develop in Projective Verse became important for his group. Simplest is an implication of the then relatively unexplored technology of the typewriter. Olson's interest in orality and the typewriter is not a paradox: the machine's precision with visual layout could give, he thought, a more exact indication of how the structures of a poem are meant to be sounded. Gaps are pauses; spacing is a kind of musical 'scoring'. The typewriter is technology for the new orality. Though Thomas Edison had recorded poets (Browning, Tennyson, Whitman), and though some poets (including Olson's 'master', Ezra Pound) had recorded extensively before 1950, and though recording shows much more about the aural qualities of a poem than the typewriter, Olson had nothing to say about it.

Also significant is that "breath allows all the speech-force of language back in' (244). This is not only about the individual: it is about reclaiming for poetry the energies of the language as spoken by the whole community, not the more cerebral discourse norms of an educated elite. In this Olson may sound in part like a succession of programmes for change in English poetry, but his meaning is more radical: by 'all the speech-force of language' he also means that 'the conventions which logic has forced on syntax must be broken open' (244). ${ }^{4}$

That is Olson's programme: the breath, and through the breath the whole body; the spoken language and its syntax; new technology to notate 
more precisely in print how the poem is to be realised as sound. This is not a programme purely about the aesthetics of poetry. Olson's manifesto is not confined to issues of poetic form. From the beginning Olson aims to 'suggest a few ideas about what stance toward reality brings such verse into being' (239). This is not just a new aesthetic: it is about new modes of perception. As Olson puts it in the shorter and sketchier Part II of the manifesto: 'If the beginning and the end is breath, voice in its largest sense, then the material of verse shifts. It has to' (247).

In considering that shift Olson cites as exemplars Homer (oral epic) and three dramatists - poets writing not for print but for the voice. He posits a fundamental distinction between those who live in and compose for oral cultures-Homer, Euripides, Shakespeare, the Japanese playwright Zeami Motokiyo-and those who live in, think within the norms of, and write for print cultures. Olson's claim is that writers for print work from a lyric ego in which the human is experienced as separate from the rest of nature; their subject is the bounded ego, and their methods are learned from the traditions of bounded egos. Writers for the voice work from a physiology in which the human is experienced as part of nature; their subject is the whole of nature of which they are a part, and their methods are congruent with that rootedness in nature. Whatever mixture there may be in this of truth and enabling myth, understanding its possibilities requires a new approach to reading poetry - thinking about poetry in relation to the body, the breath, and the ear; reading with the eye only insofar as the eye assists and directs the ear with finding the sound; using the notation on the page as a key to realising all the sounds of a poem in the voice and to the hearing.

Olson's aim was to create new work for what he regarded as a new phase of civilisation, the world as it was being reconstructed after the cataclysm of World War II. The use of the atomic bomb at the end of the war indicated that real apocalypse was a possibility. Humanity could now destroy itself. Immediate post-war changes added to this the communist revolution in China; the huge extension of Soviet Russia's domination in Eastern Europe; and the beginning of the end of European empires in Asia and Africa: 'now, 1950' really seemed a new world. Olson also emphasised the new intellectual position of the age of relativity in physics and the intellectual and moral relativities that could be seen as following from that. Olson and his associates were searching for new modes of poetry adequate to the conditions and knowledge of this new world. While the focus of their experiments was aesthetic and small-scale-the 
structure of the poetic line-the ultimate contexts-social, political, and intellectual-were worldwide.

Olson enacted his theories of the breath-line literally. Regardless of the flow of sense and structure of syntax, as his recorded readings show, he usually marked the structure of the line with a break at the end. Visual recordings also show how he read using through the voice the expressivity of the whole body.

'The Kingfishers' (1949) shows the method in action. ${ }^{5}$ The fundamental issue of the poem is that of Olson's civilization: change-changes of perspective, which mean that meanings once central are lost or transformed. This is typified by the kingfishers-their real existence observed scientifically; the different perspective of myths and legends about them; and the further perspective of a vanished culture in which their beauty was so valued that their feathers operated as currency. Shifts of perspective also mean different valuations of other phenomena-ancient civilizations of South America, seen in terms of their religion of human sacrifice or their art in gold work; the mysterious 'e'-stone of the oracle at Delphi, the range of meanings of which was already conjectural in ancient times. The issue is announced by a paradox of Heraclitus, 'change alone is unchanging', or in Olson's version:

What does not change / is the will to change

Like the kingfishers, like other aspects of nature and culture, the human perceiver is also subject to perpetual change. Again Olson quotes Heraclitus: 'Into the same river no man steps twice' (perpetual change in nature); 'No one remains, nor is, one' (perpetual change in the human).

The mode of poetry that embodies this universal fluidity of being, culture, and perspective is the antithesis of the static, finished artwork emblematised by the New Critical image of a poem as a 'well-wrought urn'. It must embody the never settled, ever-shifting, perpetually in process. The breath-structured line is its vehicle. What Olson aimed for with this he was beginning to theorise: a mode by which the fixities of print imply the fluidities of orality. He is a performance poet for whom publication on film is a near-ideal medium. His manner of handling language on the page - the incomplete syntax suggesting speech; the breath-punctuating line structures emphasising performance in the living moment-is YouTube for the 1950s. Despite Olson's statements, it is not always the precise notation that is important so much as the mode 
of performance and orality suggested by his structuring of the printed layout. The breath's structuration of the line is less significant than the implied presence of the living breath in every aspect of performance.

Having begun with a paradox about change, and developed the idea through various epitomes of change, fluidity, shifting viewpoint, and perspectival interpretation in open-ended conjunction, 'The Kingfishers' ends paradoxically, with a question juxtaposed with an ambiguous affirmation.

Shall you uncover honey / where maggots are?

I hunt among stones

Are the stones a source of wisdom? If they are, can they yield their wisdom to the seeker now? Or are they only a source of meanings attributed by the perspective of the interpreter rather than elicited from the object? The central stone in the poem, the stone of the Delphic oracle, epitomises these doubts. And what is the meaning of juxtaposing this ambiguous affirmation with its apparent opposite?

if I have any taste

it is only because I have interested myself

in what was slain in the sun

The poem closes with contrasting searches, of stones and maggots: mineral-immutable and animal-ephemeral. These searches take place in a new world the perspectives of which are undergoing profound changes. The methods of poetry's search for meanings must change with these shifts of perspective. As the poem puts it, 'When the attentions change' then the object of attention 'sounded otherwise / was differently heard' ('sounded ... heard' maintains the doubt about elicited and attributed meanings). What Olson adds to Ezra Pound's Modernist reorientations goes beyond what Pound identified as foundational: 'to break the pentameter, that was the first heave' (Canto LXXXI). Olson aims to abolish the ghost of any recognised meter. He proposes a new indeterminate structural fluidity of the line based on 'the breathing of the man who writes, in the moment that he writes'. Written while Olson was formulating Projective Verse, 'The Kingfishers' shows both the method of the breath-structured line under development and its underlying raison d'être. 
Among the most significant contemporary responses to Olson was that of William Carlos Williams. In his Autobiography Williams quoted Projective Verse with this introduction: "Until we have reorganized the basis of our thinking in any category we cannot understand our errors. An advance of estimable proportions is made by looking at the poem as a field rather than as an assembly of more or less ankylosed lines' ('ankylosed' - of two bones: grown together so firmly as no longer to move upon each other; referring to what Williams sees as the inflexibility of traditional metrical structures). ${ }^{6}$ The advance to which he refers he described as 'well illustrated by Charles Olson in the following' (a quotation from Projective Verse running over four pages). This is often seen as straightforward endorsement of Olson, but the presentation is ambivalent. Williams counterpoints his extended quotations from Olson with an account of the house of the American painter Charles Sheeler and his Russian wife, Musya Sokolova. This house for Williams emblematised a 'poem', extending the idea to include all imaginative creations, and describing 'the reconstruction of the poem as one of the major preoccupations of the intelligence in our day' (332). Built in the American Colonial era, modelled on British and Dutch architecture, the house incorporated Sheeler's Welsh family background, the American Shakers whose furniture he collected, and Sokolova's ability 'to transfer an understanding from an aristocratic past ... to this context' (334). For Williams it was an architectural 'poem' that brought into contemporary unity American and European elements. He set this beside selections from Projective Verse without comment, but the juxtaposition implies something other than straightforward endorsement, characteristic of Williams' manifestos, which are more tentative than Olson's polemic, more openly searching for what he professedly cannot fully articulate. ${ }^{7}$

And with Williams more than with Olson there is a disjunction between theory and practice. This can be considered through a reading Williams gave at Harvard 1951, where he began by offering some fundamental orientation. 8

All art is sensual. Listen. Never mind. Don't try to work it out. Listen to it. Let it come to you. Let it ... Sit back, relax, and let the thing spray in your face. Get the feeling of it. Get the tactile sense of something ... something going on. It may be that you will then perceive ... have a sensation that you may later find will clarify itself as you go along. So that I say don't attempt to understand the modern poem: listen to it. And it should be 
heard. It's very difficult sometimes to get it off the page, but once you hear it, then you should be able to appraise it. In other words, if it ain't a pleasure, it ain't a poem.

Hear the poem; enjoy whatever you receive; do not puzzle about meaning-advice that can be paralleled from any number of twentiethcentury poets. Williams is responding to a typical misleading way of addressing difficulty in modern poetry: the supposition that the reader needs to know something beyond the poem, whereas what the reader really needs is to dwell receptively on what the poem itself gives, and not see it but hear it. Williams acknowledges, however, that making the printed page reveal an aural structure can be difficult. His own readings suggest that the poem as printed can be positively misleading about the structure the poet imagined-as can be heard in his performance in this same reading of 'The Yachts'.?

'The Yachts' has features of the European poetry that in theory Williams was aiming to do without. It is written in a pattern that looks like terza rima - the form of the Divina Commedia, with some traditional patterning of verbal music and a sort of 'poetic diction' (words definitely not from American demotic). A marked feature is a change of direction in the final stanzas. The opening admires the yachts: they are beautiful; in the protected environment in which they exist, 'they appear youthful, rare // as the light of a happy eye'; though they need to negotiate difficulties, when 'the waves strike at them ... they are too / well made, they slip through'. But finally the poem prompts the reader to see the yachts as symbols of their rich owners as they operate in society: from one perspective beautiful, within limits superbly equipped for resisting natural disaster; but from another perspective-when 'the horror of the race dawns staggering the mind'-causing suffering to which they are culpably indifferent. In the Harvard reading, Williams explains that the poem was written during the Depression of the 1930s, and comments simply, 'At that time there was a good deal of misery, and that is why the poem came to be written'. Elsewhere he is more explicit about a political meaning: the last stanzas show 'the real situation (of the poor) [which] is desperate'. 10

In giving the poem aural shape Williams is the converse of Olson: except insofar as formal breaks coincide with syntactic breaks, he ignores 
the printed form and phrases for the syntax. The visual form of the poem on the page could not be reconstructed from Williams' reading. In reading for the syntax Williams observes one form of the poem's breath structure, but not that notated by the poem's printed form, which follows loosely a structure from European tradition. Also notable is the change of pace and intensity with which he conveys the drama and pathos of the final stanzas. Nothing the typewriter could do with form on the page could convey this. The actual sound of the poet's voice is needed. Recording, not the typewriter, is the technology that makes audible the soundscape of the poem imagined by the poet.

This issue of some kind of structuration distinct from the forms that had been those of European poetry since Homer, modes capable of expressing profoundly new conditions of existence, has been a recurring preoccupation of modern and contemporary poetry. Olson's formulation of structures based in the breath had an immense effect on American poetry of the second half of the twentieth century. ${ }^{11}$ How significant this was as a response to conditions after 1945 is evident in the similar experiments with the idea of a breath structure for the poetic line conducted contemporaneously, but independently, by Paul Celan in German poetry.

Like Olson and his followers, and for reasons that have some contextual similarity, Celan proposed new ways of thinking about the structures of poetry in terms of breath. To understand what Celan proposed, and why, it is necessary to consider the contexts in which he was writing, and specifically his sense of the need for new ways of writing adequate to all that is signified by the Holocaust. The extreme horror of what had happened meant that any treatment in art that presupposed recognisable aesthetic norms constituted a betrayal. Poetry could not be silent, but neither could poetry speak as it had spoken.

Celan's poetry is therefore difficult-fragmentary, oblique, enigmatic, speech on the verge of silence. It demands commitment to reading as an act requiring supreme attention: intellectual effort and imaginative engagement that respects the commitment of the poet. This demand cannot be compromised or mitigated. It is essential to the poetry's expressivity that articulation is pressing against a limit of possibility bound up with every aspect of its struggle to come into being at all. Despite this, Celan's poetry has spoken powerfully to post-War German culture, and 
not only to German culture but in translation to other parts of Europe and to the English-speaking world.

One way of addressing the poetry's difficulty is by reading it aloud. That is Celan's advice. 'Hör dich ein / mit dem Mund': listen your way in with the mouth ('Die Posaunestelle', 'The Trumpet's part', Zeitgehöft, Homestead of Time, 1976). In this way the reader discovers what Celan described as the breath-structure of a poem. This endorses the advice of Paul Valéry (one of the many poets Celan translated):

Verse ... holds an admirable and very delicate balance between the sensual and intellectual forces of language. [When studying a poem] ... do not be in a hurry to reach the meaning. Approach it without forcing and, as it were, imperceptibly. Attain the tenderness and the violence only by the music and through it. ... Remain in this purely musical state until the moment the meaning, having gradually supervened, can no longer mar the musical form. You will gradually introduce it as the supreme nuance which will transfigure your piece without altering it. ${ }^{12}$

This is congruent with the advice of William Carlos Williams: 'don't attempt to understand the modern poem: listen to it'; and not only 'listen', but get the poem off the page into your whole auditory and acoustic being. Hear a poem by speaking it. ${ }^{13}$

Getting to know a poem through the voice is one method. Another, also fully appropriate to Celan, is suggested by Keats: living with a poem so that it evolves into your whole being: 'wander with it, and muse upon it, and reflect from it, and bring home to it, and prophesy upon it, and dream upon it'. 14 'Wander with', 'muse upon'-free, undirected thinking: 'wander with', remaining in the words; 'muse upon', taking flight with the subject; 'reflect from', movement outwards, beyond the self; 'bring home to', movement inwards, to the self; 'prophesy', the response of conviction; 'dream', the response of meditation. This is not a discipline of criticism: it is a gamut of how to live with a poem and make it your own.

Reading in this way, accepting the freedom of the reader to wander, to muse, letting the mind move outwards into the world, engaging the idiosyncrasies of experience-this accepts that meaning is unfixed. Meaning comes from the poem; meaning comes also from the reader. Celan was interested in images with meanings that exist 'beyond our 
wakeful thinking', images the light of which is not daylight. ${ }^{15}$ Even in his early poetry, where articulation is less oblique, he encourages reading open to the reader's imaginative inflection.

\author{
Mit wechselndem Schlüssel \\ schließt du das Haus auf, darin \\ der Schnee des Verschwiegenen treibt. \\ Je nach dem Blut, das dir quillt \\ aus Aug oder Mund oder Ohr, \\ wechselt dein Schlüssel. \\ Wechselt dein Schlüssel, wechselt das Wort, \\ das treiben darf mit den Flocken. \\ Je nach dem Wind, der dich fortstößt, \\ ballt um das Wort sich der Schnee.
}

\begin{abstract}
With a variable key
you unlock the house in which drifts the snow of that left unspoken.

Always what key you choose

depends on the blood that spurts

from your eye or your mouth or your ear.

You vary the key, you vary the word that is free to drift with the flakes.

What snowball will form round the word depends on the wind that rebuffs you. ${ }^{16}$
\end{abstract}

The house to be unlocked is the poem; the variable key is the readerwith his or her own embodied mindscape (eye, mouth, ear), his or her own context (wind that rebuffs). In Celan's later work the reader's freedom crucially includes freedom in eliciting from the poem, and finding through his or her own discovery of the poem, its expressive structuration by the breath.

With poetry that presses language to the extreme boundaries of expressibility, there are special difficulties for the non-native speaker, especially since Celan so consistently exploits nuances of etymology, semantic implication, and verbal sound, ultimately contributing to what he came to regard as the all-important breath-structure implied by all these elements taken together. No translation can preserve all the elements that contribute to this. Only a reader with a native speaker's fluency can grasp all the implications of Celan's diction and syntax, phrasing, inflection, and intonation. Nevertheless, as a copious translator himself Celan actively endorsed reading poetry in translation, and he has been served by dedicated and brilliant translators. ${ }^{17}$ Though some meanings of music and structure will always be lost in translation, major aspects of a poem can be carried over into the new language; and Celan suggests principles of listening to the structures of poetry, hearing the music that is meaning, that are applicable to poetry in any language.

Celan was a Jewish German-speaking Romanian. His parents were deported from Romania in 1942 to camps in German-occupied Ukraine. Shortly after their deportation he became part of a Jewish forced labour battalion. His father died in late 1942, and in late 1942 or early 1943 his mother was shot as unfit for work. There would evidently be problems for 
any writer of finding modes of articulation adequate to these experiences. For a Jewish writer, writing in German, the problems were acute. German was for Celan the language of murderers. ${ }^{18}$

The most famous of Celan's early articulations about Nazism is 'Todesfuge' (Deathfugue). The poem is uncharacteristic in its amplitude and in its direct treatment of the subject of the camps and the Holocaust. Its repeated lines and parallel phrases, which suggest both the horror of terrors and the obsessions caused by fear and suffering, are quite unlike the pared-down implicatory understatement of Celan's later work. The poem is spoken by a prisoner who reports the actions and words of a guard addressing prisoners. The guard has blue eyes and writes to a woman with blonde hair called Margarete: they are archetypal Aryans. The other woman addressed in the poem has a Hebrew name, Shulamith, the name of the beloved in the Old Testament Song of Songs. Even for somebody who does not read German, hearing Celan's commitment to the poem in his reading is a striking experience. ${ }^{19}$ Unlike William Carlos Williams, who supplies in performance the punctuation he eschews on the printed page, Celan reads with the same absence of punctuation as he writes, which is a notable aspect of how the text signifies. The breath structure is not that of normal speech but of somebody too terrified to breathe freely. Read in this way, the poem presents not clearly differentiated voices but a single mind echoing with alien voices so burned into it as to have become inescapable horrifying presences.

The poem is not typical of Celan in its manner, and it has been criticised as too conventionally 'poetic' for its terrible subject-a critique congruent with a famous statement about poetry and the Holocaust by the cultural theorist Theodor Adorno: 'To write poetry after Auschwitz is barbaric. And this corrodes even the knowledge of why it has become impossible to write poetry today'. ${ }^{20}$ This has attracted a library of comment. It is a formulation that achieved wide currency more for the glamour of extremity than the humility of truth. It would make sense in a more modest form: 'Poetry must change radically after ...', after the Holocaust, as also (one focus of Olson and his associates) after Hiroshima and Nagasaki-because of the knowledge of what has been done, and the knowledge of what can now be done. But 'poetry must change' is a completely different proposition from the contention that to write poetry is barbaric-by which Adorno indicted poets such as Celan who continued to write, and to write specifically in response to the Holocaust. Celan, who wrote partly as a way of keeping some sense of humane 
activity alive, offered a bitterly ironic comment on this in a letter about a politically correct journal which followed Adorno's line. ${ }^{21}$ Nevertheless, under his own internal pressure to find adequate modes of utterance for the all but unutterable, Celan did look for radically new modes of writing. It was in his search for these that he became newly conscious of the role of breath in poetic structure.

He expressed a preliminary idea of the need for fundamental change in response to a Paris bookshop questionnaire in 1958-the need for German poetry to have a new sound, because the old music of poetry could not match up to the knowledge of the present, that is, after the Holocaust.

No matter how alive its traditions [the traditions of German poetry], with most sinister events in its memory, most questionable developments around it, it can no longer speak the language which many willing ears seem to expect. Its language has become more sober, more factual. It distrusts 'beauty'. It tries to be truthful. If I may search for a visual analogy while keeping in mind the polychrome of apparent actuality: it is a 'greyer' language, a language which wants to locate even its 'musicality' in such a way that it has nothing in common with the 'euphony' which more or less blithely continued to sound alongside the greatest horrors. ${ }^{22}$

How did Celan evolve this new mode of utterance? Unlike many twentieth-century poets who wrote criticism copiously as a way of proselytising for the principles by which their own work should be understood, Celan wrote little critical prose. His only extended statement of poetics is his 1960 speech of acceptance of the George Büchner prize, Der Meridian. $^{23}$

This is a difficult text, in part inherently, in part because of the way in which Celan articulates his poetics by reference to Büchner. As with Celan's poetry, so with his prose: his modes of utterance embody the difficulty of speaking at all. His statements are the reverse of polemical, manifesto-like, announcing the programme for a new movement, in the manner of Olson. On the contrary, they are tentative, fragmentary, gnomic, working out ideas that remain all but resistant to articulation. He incorporates a defence of the mode from Pascal: 'Ne nous reprochez pas le manque de clarté puisque nous en faisons profession' (Do not reproach us for a lack of clarity because we profess that for ourselves; $\$ 27)$. The context of this in Pascal is a discussion of how the Old Testament is 
interpreted in the New Testament, following the interpretations of Christ himself (Luke, 24.44-45) - that is, in terms that require considerable reading in. The commentator on Pascal from whom Celan took Pascal's remark introduces it with injunctions similarly in accord with Celan's thinking: 'flee from brightly lit places because bright light makes you see a lie; love the half-lights, the shadows' (227).

Characteristically, Celan can only approach his central idea of the 'breathturn' essential to the really new in poetry obliquely. What is really new does not admit of formulation without experiment and indirection groping towards some element of what is to be discovered. One form of indirection is extreme syntactic convolution.

Gewiss, das Gedicht—das Gedicht heute—zeigt, und das hat, glaube ich, den noch mittelbar mit den—nicht zu unterschätzenden-Schwierigkeiten der Wortwahl, dem rapideren Gefälle der Syntax oder dem wacheren Sinn für die Ellipse zu tun,-_das Gedicht zeigt, das ist unverkennbar, eine starke Neigung zum Verstummen.

Certainly, the poem-the poem today-shows, and this, I believe, has to do only indirectly with the - not to be underestimated-difficulties of word choice, the faster fall of syntax or the more lucid sense of ellipsis- the poem shows, unmistakably, a strong tendency to fall silent. $(\$ 32 \mathrm{a})$

The expressive aurality of that is written into the syntax and punctuation, though fully to realise those the reader must use not the eyes but the mouth. But what would one not give to hear the breath structures (intonation, inflection, pause) by which Celan delivered what written notations can only imply within limits.

Hesitation, interruption, circuitous syntactic involution, is combined here with overt expression of difficulty: a 'lucid sense of ellipsis', that is, perceived lacunae - things not expressed that must be supplied, whether by the implications of the poem or the imagination of the reader we are not told; and a 'faster fall of syntax', that is, syntax that omits connectives, that does not include all the elements that might fix the syntactic relations of words. Both of these aspects of expression, present in this prose as in the poetry it searches to envisage, problematise meaning. Insofar as articulation can, they foreshadow a 'tendency to fall silent'. They are to be heard with 'Hasenöbrchen' (hare's ears) - with a special sensitivity to implication, listening 'beyond ...the words' $(\$ 48 \mathrm{c})$. With poetry this means the implications of image, syntax, and formal structure-and, as Celan goes 
on to say, finding within the syntax, the form, and the inflections and intonations implied by meaning the structure of the living breath.

Occasionally in all this there are syntactically simple sentences, but then another kind of difficulty supervenes: 'Das Gedicht ist einsam. Es ist einsam und unterwegs. Wer es schreibt, bleibt ibm mitgegeben' (The poem is lonely. It is lonely and en route. Its author remains added to it; $\$ 34$ ). The wisest expositor may leave that to the reader's contemplation.

Obliquity, indirection, qualification, the gnomic are built into the mode of expression. The struggle to achieve articulation is also built into the document itself, more evidently than is represented by print. The typed reading script from which Celan delivered the speech is covered in re-phrasings, deletions, and additions. Everything about Der Meridian, from its style to its material form, is an expression of living speech, of unconcluded search, the continued presence in the language, and the material record of the occasion, of the unrepeatable moment of its spoken delivery, incorporating varied refusals of finality.

Another problem of the speech is that Celan articulates his poetics by continuous reference to Büchner, with whom he signifies a sense of deep kinship. The fundamental starting point of this is Büchner's modernity. Born in 1813, Büchner was a political revolutionary who lived in the reactionary aftermath in Germany of the Napoleonic Wars. His writings are so unusual that they were ignored in his lifetime and for the halfcentury following. He was rediscovered in the early twentieth century as a precursor of Modernism. What he has in common with Celan is an aesthetic related to new political and social realities that require new ways of writing and reading. What he signifies for Celan is letting life back into art by a radical overthrow of aesthetic conventions. While Celan regularly shies away from affirmations, he asks of Büchner's work whether it does not 'propose... a truly radical calling-into-question of art' $(\$ 19)$. His implied answer is that it does.

Celan extracts central ideas about his own aesthetics from two of Büchner's works, the play Danton's Death (about the execution of the French revolutionary leader) and the novella Lenz. The central figures in these for Celan are Lucile Desmoulins, wife of an executed revolutionary, in Danton's Death, and Jakob Lenz, the 'hero' of the novella, both alienated characters who do not fit into their surroundings. Though 'blind to art'-that is, valuably ignorant of its conventions-Lucile is a proto-poet in seeing language as 'person-like and tangible' $(\$ 6 \mathrm{c})$. The evidence of her alienation comes in the final moment of the drama, when, next to 
the revolutionary scaffold, she shouts 'Vive le roi!', thus bringing about her own execution. For Celan this has nothing to do with the meaning of the words-tradition, the past, support for the ancien régime: it is an

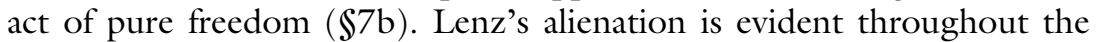
novella but becomes more intense towards the end when he is unable to bear what he hears as the voice of silence all around him. Celan picks one detail of his alienation to epitomise the whole, his momentary wish to walk on his head with the sky an abyss above him: this epitomises the 'breathturn' towards a new way of being which increasingly drives him away from people who see the world in conventional terms. Both figures are analogies for Celan as poet.

Celan's association with Büchner suggests that the problems he addresses are trans-historical, the problems of the revolutionary artist in any age. Other invocations in the speech carry the same implication, especially the invocation of Mallarmé $(\$ 19)$. Mallarmé signifies for Celan the previous fundamental revolution in poetics, at the end of the nineteenth century, which generated endless experiment and interpretation, and which, like Celan, emphasised the centrality of sound and form in poetry to meaning. 'Should we before all ... think ... Mallarmé through to the end?', Celan asks. The Mallarmé revolution has implications yet to be realised-new and more intense explorations of aurality, more entirely by the ear, but with no 'pure music' separation from semantic content and history. More simply, the invocations of Mallarmé, Pascal, and others imply that the problems Celan addresses are transhistorical.

Celan also uses Büchner, however, to suggest that the permanent problem of the really new in art also has a precise historical locatedness for the difficulties of poetry in his historical moment. Lenz begins on 20th January. In the novella this is a minor detail, but in the speech Celan mentions it four times, twice $(\$ 44 \mathrm{e})$ affirming its importance in relation to his own poetry. 20th January 1942 was the date of the Wannsee Conference, held to arrange implementation of the so-called 'final solution' of the Jewish question - the extermination of Jews in all German-held territories. Celan certainly knew this date: the minutes of the meeting (the so-called 'Wannsee Protocol') figured prominently in the Nuremberg warcrimes trials. Celan's stress on poetry being mindful of its dates must have this in view. 
Perhaps one can say that each poem has its own ' $20^{\text {th }}$ of January' inscribed in it? Perhaps what's new in the poems written today is exactly this: theirs is the clearest attempt to remain mindful of such dates?

$(\$ 30)$

The date signifies the historical context of the Holocaust as prompting post-war poetry's necessary search for new modes of expression.

Celan leads through Büchner to these new modes, to the necessary radical 'breathturn'.

Lenz-or rather Büchner-has here gone a step further than Lucile. His 'Long live the king' is no longer a word, it is a terrifying falling silent. It takes away his-and our-breath and words.

Poetry: that can mean an Atemwende, a breathturn. Who knows, perhaps poetry travels this route-also the route of art-for the sake of such a breathturn? ... Perhaps here, with the I-with the estranged I set free here and in this manner-perhaps here a further Other is set free? $(\$ 29 \mathrm{a} / \mathrm{b})$

Identifying the 'breathturn' with two moments in Büchner that he interprets as evidence of full human presence, Celan speculates, or postulates, that this may be what a poem can give. With his usual tentativeness, Celan does not affirm: he questions, and with a reiterated 'perhaps'. This 'breathturn', this moment of full human presence, is found not by any means that could be thought of as connected with skill in manipulating words. The primary issue is living a life of spiritual openness and discovery. But the postulated route is 'also the route of art'. To reject the musicality, craft, skill with words associated with styles of poetry that the new conditions of the post-Holocaust world have rendered archaic is not to reject art: there is still a new art to be found.

The Meridian drafts, and the poems written in the last decade of Celan's life, associate that with the sense of living presence located in a poem's breath structure.

Twice, with Lucile's 'Long live the king', and when the sky opened as an abyss beneath Lenz, the Atemwende, the breathturn seemed to happen. Perhaps also when I tried to set course toward that inhabitable distance which finally becomes visible only in the figure of Lucile. $(\$ 43)$

Again the same tentativeness: it seemed to happen; and again 'perhaps', as preface to his own 'breathturn', possibility of fully human being. 'When 
I tried to set course towards ...': when he attempted to understand and to write without evasion the experiences resulting from the war.

In the final paragraphs of Der Meridian $(\$ 45 \mathrm{c})$ Celan quotes from his own sequence, Stimmen (Voices).

Stimmen vom Nesselweg her:

Komm auf den Händen zu uns.

Wer mit der Lampe allein ist, hat nur die Hand, draus zu lesen.
Voices from the nettle path:

Come on your hands to us.

Whoever is alone with the lamp

has only his hand to read from. ${ }^{24}$

Voices from the path of pain invite him to join them, through whatever difficulty and suffering; they tell him of a moment of illumination which has to be approached alone, and understood in terms of one's own experience. Of this poem he says, 'I had ... encountered myself' $(\$ 45 f)$, a comment he elaborates with a paradox about poems reaching into the future to encounter the past: poems are 'a sending oneself ahead towards oneself, in search of oneself ... A kind of homecoming' $(\$ 46)$.

Two later poems in the same sequence are especially significant:

Stimmen, vor denen dein Herz ins Herz deiner Mutter zurückweicht.

Stimmen vom Galgenbaum her, wo Spätholz und Frühholz die Ringe tauschen und tauschen.
Voices from which your heart

shrinks back into your mother's heart.

Voices from the gallows tree, where latewood and springwood change and exchange their rings.

This encounter echoes with the past: his love for his mother, and her murder; and with the same sense of the future being an encounter with the past, 'latewood and springwood': the existent changing through its encounter with the new discovered by the poem. Similarly the final lines of a section that begins from the archetypal conflict in Judaic history between the brothers Esau and Jacob:

Wir wohnen darin. We dwell inside.

Atme, dass Breathe, that

sie sich löse. it come loose.

In the sequence as a whole people are trapped in what confines their full humanity by histories which are immediate and personal but also archaic and cultural. The freed breath epitomises everything that can lead through those confinements to a more full humanity.

Fragments from drafts for The Meridian that did not find their way into the speech itself treat the issue of breath somewhat differently. One group is less metaphysical, less mystical, more like the ideas of Olson and 
his associates. They imply 'hör dich ein / mit dem Mund': understand a poem through familiarity with its shape-but not only its shape on the page; also shapes discovered by finding its structures of phrasing through performance.

'What's on the lung, put on the tongue', my mother used to say. Which has to do with breath. One should finally learn how to also read this breath, this breath-unit in the poem: in the cola meaning is often more truthfully joined and fugued than in the rhyme; shape of the poem: that is presence of the single, breathing one.- (108)

Three fragmentary notes help to explain this:

'Breath-units' (Buber); cola
Mora, cola
In the mora meaning clarifies itself-

The great historical Oxford English Dictionary does not recognise 'cola' as having a meaning in relation to prosody; but it recognises Celan's synonym, 'mora': OED, n. ${ }^{l}$, 3.a. Prosody. A unit of metrical time equal to the duration of a short syllable. Celan understood 'cola' as equivalent to a term he apparently found in the theologian, Martin Buber, 'breathunits' (Atemeinheiten). Whether the term indicates the unit, or the space marking the end of the unit, the claim is that hearing the breath structure of a poem is fundamental to feeling its meaning. But hearing this structure is much more an act of interpretation with Celan than with Olson, because Celan does not aim to convey this by the lineation of the poem as printed. This is apparently Celan's meaning when he describes a poem as 'the trace of our breath in language' (115).

There are also more metaphysical fragments not worked into the speech related to the idea of the 'breathturn'.

I have survived some things, - but survival / Überstehn / hopefully isn't 'everything'-, I had a bad conscience; I was searching for-maybe I can call it that?-my breathturn.

The bad conscience that prompted Celan to seek the profound redirection for which he again uses his invented word, breathturn, can be, but need not be, interpreted in personal terms. What is clear is that survival is not enough. There must be a search beyond trauma-personal trauma and cultural trauma - to recover a more full humanity. 
In another fragment, poetry takes away the false breath by being a revelation of things as they really are.

Lenz: the Medusa-likeness of poetry-to: faces you with silence, it takes your-false-breath away; you have come

$/ / / /$ to the breathturn. (123)

The Medusa, whose gaze turns what it looks at to stone, indicates both a possibility and a limitation. A possibility-freezing a human moment that is utterly real, its reality not compromised by conventions of representation or the perspective introduced by a human point of view; but also a limitation: where the purpose of this freezing is to capture the reality of the living moment, the paradox that the reality of that moment depends on its having a before and after. How can art capture the living without the loss built into the very idea of capture?

This may be an irresolvable paradox: hence the tendency of the poem to fall silent. Celan's later poems have nothing like the extension and rhetorical elaboration of 'Todesfuge'. They are characteristically no more than a few lines, sometimes organised in short sequences or loosely related groups as a way of extending utterance. Everything combines to convey the fundamental difficulty of achieving articulation at all. But while the individual utterance is short the totality of utterances is extended-brief, but compelled.

'Fadensonnen' is a typical late poem from the collection Atemwende (Breathturn).

\begin{tabular}{|c|c|}
\hline $\begin{array}{l}\text { Fadensonnen } \\
\text { über der grauschwarzen Ödnis. } \\
\text { Ein baum- } \\
\text { hoher Gedanke } \\
\text { greift sich den Lichtton: es sind } \\
\text { noch Lieder zu singen jenseits } \\
\text { der Menschen. }\end{array}$ & $\begin{array}{l}\text { Threadsuns } \\
\text { above the greyblack wastes. } \\
\text { A tree- } \\
\text { high thought } \\
\text { grasps the light-tone: there are } \\
\text { still songs to sing beyond } \\
\text { mankind. } 25\end{array}$ \\
\hline
\end{tabular}

Celan drew attention to this poem by making the invented word, 'Fadensonnen', the title of his next book, suggesting that it strikes a keynote. 'Fadensonnen' can be perceived in many places: weak signs of light (threads) contrast with the context, 'the greyblack wastes' which are their antithesis. A tree-high thought may not, as some readers think, stretch up to heaven, but it is surely high, and manages to grow out of the grey-black wastes; and what it attaches itself to-another invented word, 
'Lichtton'- has the power of addressing the eye and the ear. In this wasteland there is something growing; and presumably the 'light-tone' it grasps is connected to the 'thread-suns'. But what is most surprising about the tentative hope expressed in these images is the conclusion drawn from them. Poetry has to reach beyond what has so far been conceived: that is fundamental to Celan's post-Holocaust situation, and must be at least part of the idea of the 'breathturn' that is this volume's title. And what is usually conceived in terms of the barely utterable, articulation on the verge of being overwhelmed by silence, is here conceived as potentially 'Lieder zu singen', songs to sing. The images of tentative hope prophesy a new poetry not so near the verge of silence as Celan elsewhere suggests. Its 'music' will be a new music, but that it should be conceived as song is striking.

Breath is heard in everything about the realisation of a poem in the voice, including the imagined voice. This means not only those elements of the poem which have a visual form on the page-its formal and syntactic structure-but everything implied by form and meaning. It includes not only what Ezra Pound called the 'sculpture of rhyme' (threedimensional seeing: what the flat surface of the page implies beyond what it literally shows) but also its music - the sounds that are realisations of the visible; rhythm, rhyme, line-length, every formal shape. It also includes the sounds derived from structures implied by sense and form: pause, dynamics, inflection, intonation, all of which are variable and subject to interpretation.

Olson's ideas of the breath-line relate primarily to his poetry and the poetry of his associates and followers. Though half-endorsed by William Carlos Williams, and apparently helpful to his own different experiments and conclusions, they do not apply to how Williams actually read his own poetry. Celan's less precise but more searching ideas on breath in poetic structure apply widely to English and American poetry since Modernism. Potentially they apply to feeling meaning through structure in all poetry.

That there is a breath structure written into the poem, essential to experiencing the poem as living speech, to be elicited variously by different readers, is the central idea to which Celan's searching leads. Such a structure is not simply objectively present. Celan is clear that in their every aspect poems are read with the changing key of the individually idiosyncratic and culturally situated reader. As Celan accepts, and positively argues, the breath structure of a poem is heard differently by different readers, depending on individual sensibility and context. That 
does not mean that perceiving it is fanciful, or substantially make it different from all the other features of meaning in poetry that competent readers can agree are present, though they may not agree what they are or how they function. But Celan is not interested in a discipline of criticism. What he offers is a way of bringing the reader into real and living relation with a poem.

This depends in part on what T. S. Eliot calls 'the inexplicable mystery of sound' in poetry. ${ }^{26}$ For those who have ears to hear, Celan understands those sounds as gathered together in the breathing: form, structure, syntax, inflection, intonation, tone; expressions of the whole physical being-passion, humour, intensity, volume-(Olson) reaching down through the throat of the person who writes, to the lungs, the diaphragm, and the whole physiology of breathing; (Valéry) by engaging the body, integrating the intellectual and the sensual.

Celan extends Valéry's claim that 'syntax is a faculty of the soul'. ${ }^{27}$ In poetry every inflection of the sounds of language has meaning. For Celan Valéry's syntax is synecdoche for all the expressivities of articulation dependent on the breath: how words are uttered because of the whole framework of meaning and form within which they are situated. What this was for the poet recording tells more fully than print, but that is no more authoritative and final for the reader than a composer's recording of a musical work for a performer. Though it has a special status as an interpretation, it is finally one interpretation among many. What this might be for each reader-accepting, as Celan does, that for each reader it will be different - can be discovered by living with a poem, and living with it through the voice: 'hör dich ein mit dem Mund'.

\section{Notes}

1. The literary contexts and the influence of Olson's work can be seen in two frequently reprinted and widely distributed anthologies: The New American Poetry 1945-1960, ed. by Donald M. Allen (New York: Grove, 1960); The Poetics of the New American Poetry, ed. by Donald Allen and Warren Tallman (New York: Grove, 1974).

2. For the influence of Olson in British poetry see Other: British and Irish Poetry since 1970, ed. by Richard Caddel and Peter Quartermain (Hanover, NH: Wesleyan University Press, 1999).

3. Charles Olson, Collected Prose, ed. by Donald Allen and Benjamin Friedlander (Berkeley: University of California Press, 1997), 239-49. 
4. For a similar programme of getting the spoken language back into written prose through breath structures see Jack Kerouac, 'History of the Theory of Breath as a Separator of Statements in Spontaneous Writing' (1962, typescript with manuscript corrections and additions), reproduced in Isaac Gewirtz, Beatific Soul: Jack Kerouac on the Road (New York: New York Public Library, 2007), 176-77; contextualised and discussed by Stefanie Heine in Arthur Rose, et al., Reading Breath in Literature (Basingstoke: Palgrave Macmillan, 2019), 91-112.

5. The Collected Poems of Charles Olson, ed. by George F. Butterick (Berkeley: University of California Press, 1987), 86-93. For Olson's 1954 recording of 'The Kingfishers' (without section III), and an extensive archive of Olson's readings, see http://writing.upenn.edu/pennsound/x/Olson. php.

6. The Autobiography of William Carlos Williams (New York: New Directions, 1967), 329.

7. For Williams' views on poetic structure formulated without reference to Olson see 'The Poem as a Field of Action' (1948), and 'On MeasureStatement for Cid Corman’ (1953) in Williams, Selected Essays (1954; New York: New Directions, 1969); cf. John C. Thirlwall, 'Ten years of a new rhythm', in Williams, Pictures from Brueghel (Norfolk, CT: Laughlin, 1962).

8. http://www.poetryfoundation.org/features/audioitem/2838. The comments on orality are at $2.40-3.50$.

9. http://www.poetryfoundation.org/features/audioitem/2838. The reading of 'The Yachts' is at 19.50-22.10.

10. Williams, Collected Poems, ed. by A. Walton Litz and Christopher J. MacGowan, 2 vols. (Manchester: Carcanet, 2000), vol. 1, 541.

11. On Olson's legacy and influence, see Mark Byers, Charles Olson and American Modernism (Oxford: Oxford University Press, 2018).

12. Paul Valéry, 'On Speaking Verse', in Collected Works, ed. by Jackson Matthews, 15 vols. (London: Routledge, 1957-75); vol. 7, On the Art of Poetry, trans. by Denise Folliot, intro. by T. S. Eliot, 162-63.

13. For Celan's recorded readings see 'Ich hörte sagen': Gedichte und Prosa (München: Der Hörverlag, 2004). Recordings of Celan reading are also available at www.lyrikline.org.

14. Letter of 19 February 1818 to J. H. Reynolds, in The Letters of John Keats, 1814-1821, ed. by Hyder Edward Rollins, 2 vols. (Cambridge: Cambridge University Press, 1958).

15. Celan, 'Edgar Jené and the Dream about the Dream', Collected Prose, trans. by Rosemarie Waldrop (Manchester: Carcanet, 1986), 3-10 (8).

16. 'Mit wechselndem Schlüssel', Poems of Paul Celan (1972), trans. by Michael Hamburger (New York: Persea, 2002), 58-59. 
17. For Michael Hamburger see note 16; also John Felstiner, trans., Selected Poems and Prose of Paul Celan (New York: Norton, 2001); Susan H. Gillespie, trans., Corona: Selected Poems of Paul Celan (Barrytown, NY: Station Hill, 2013); Pierre Joris, trans., Breathturn into Timestead: The Collected Later Poetry of Paul Celan (New York: Farrar, Straus, Giroux, 2014). All offer parallel texts in which the translation can be read alongside the original.

18. Collected Prose, 34.

19. The poem can be heard at https://www.lyrikline.org/de/gedichte/ todesfuge-66\#.WmoOxk3cvX4 and on the CD 'Ich hörte sagen' (note 13).

20. Theodor Adorno, 'Cultural Criticism and Society' (1949, 1951), Prisms, trans. by Samuel and Shierry Weber (Cambridge, MA: MIT Press, 1981), 34.

21. See John Felstiner, Paul Celan: Poet, Survivor, Jew (New Haven: Yale University Press, 1995), 225.

22. Collected Prose, 15-16.

23. Der Meridian: Endfassung-Vorstufen-Materialien, ed. by Bernhard Böschenstein and Heino Schmull (Frankfurt: Suhrkamp, 1999); The Meridian: Final Version-Drafts-Materials, ed. by Böschenstein and Schmull, trans. by Pierre Joris (Stanford: Stanford University Press, 2011). The translation is printed to parallel the layout of the German text. Section numbers $(\mathbb{S})$ and page references (numerals) are therefore the same for both texts. The speech can be read as a construction in continuous prose in Collected Prose, 37-55.

24. 'Stimmen' (Voices), Felstiner, Selected Poems and Prose, 88-93.

25. Breathturn into Timestead, 14-15.

26. 'To Walter de la Mare', Collected Poems (London: Faber, 1962), 233.

27. Collected Works, vol. 14, trans. by Stuart Gilbert, intro. by W. H. Auden, Analects, 'Odds and Ends', 15.

\section{Selected Bibliography}

Aviram, Amittai F. 1994. Telling Rhythm: Body and Meaning in Poetry. Ann Arbor: University of Michigan Press.

Bernstein, Charles, ed. 1998. Close Listening: Poetry and the Performed Word. New York: Oxford University Press.

Clark, Timothy. 1997. The Theory of Inspiration: Composition as a Crisis of Subjectivity in Romantic and Post-Romantic Writing, Chapter 11. Manchester: Manchester University Press.

Corman, Cid, et al. Encounters: American Poets on Paul Celan. Studies in Twentieth Century Literature 8/1 (1983), 101-27. 
Cureton, Richard D. 1991. Rhythmic Phrasing in English Verse. London: Longman.

Derrida, Jacques. 2005. Sovereignties in Question: the Poetics of Paul Celan. Trans. by Thomas Dutoit and Outi Pasanen. New York: Fordham University Press.

Finch, Annie. 1993. The Ghost of Meter: Culture and Prosody in American Free Verse. Ann Arbor: University of Michigan Press.

Gadamer, Hans-Georg. 1997. Gadamer on Celan: 'Who am I and who are you?'. Trans. by Richard Heinemann and Bruce Krajewski. New York: State University of New York Press.

Wesling, Donald. 1996. The Scissors of Meter: Grammetrics and Reading. Ann Arbor: University of Michigan Press.

Wright, George Thaddeus. 2001. Hearing the Measures: Shakespearean and Other Inflections. Madison: University of Wisconsin Press.

\section{SOUND RECORDINGS}

Olson, Charles. PennSound archive, University of Pennsylvania programmes in contemporary writing. http://writing.upenn.edu/pennsound/x/Olson.php. An extensive archive including video recordings.

Celan, Paul.'Ich hörte sagen': Gedichte und Prosa. Recorded 1948-67. Der Hörverlag ISBN 3-89940-450-5, 2004, compact disc.

Celan, Paul. https://www.lyrikline.org/de/gedichte/todesfuge66. Ten poems.

\section{FILM}

Kasten, Ullrich, dir. Dichter ist, wer menschlich spricht. Video recording of television broadcast, 00:52:00. YouTube. Posted by Klaus Kloßbrühe, January 3, 2016. Stuttgart, Germany: SWR, 2015. https://www.youtube.com/watch? $\mathrm{v}=\mathrm{qb}-\mathrm{dt} Y \mathrm{grIsw}$. French version: Écrire pour rester humain. https://www.you tube.com/watch? $\mathrm{v}=\mathrm{oV}$-PR9xKmNw. 
Open Access This chapter is licensed under the terms of the Creative Commons Attribution 4.0 International License (http://creativecommons.org/licenses/ by/4.0/), which permits use, sharing, adaptation, distribution and reproduction in any medium or format, as long as you give appropriate credit to the original author(s) and the source, provide a link to the Creative Commons license and indicate if changes were made.

The images or other third party material in this chapter are included in the chapter's Creative Commons license, unless indicated otherwise in a credit line to the material. If material is not included in the chapter's Creative Commons license and your intended use is not permitted by statutory regulation or exceeds the permitted use, you will need to obtain permission directly from the copyright holder.

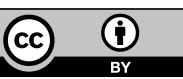

